\title{
Magia, poesia e feitiço: entre Mário de Andrade e Dante Milano
}

Alexandre Fernandes Corrêa ${ }^{a}$

\begin{abstract}
Resumo
Estudo histórico-cultural sobre singularidades literárias expressas por dois poetas brasileiros a propósito da patrimonialização da coleçãomuseu de magia negra em 1938. O pano de fundo da reflexão atinge o vasto campo do imaginário artístico do periodo modernista nas primeiras décadas do século $X X$.
\end{abstract}

Palavras-chave: poesia, Modernismo, magia, literatura. 
El mal y el bien (...) son los dos elementos irreconciliables y perfectamente inseparables de la naturaleza humana (...).

CONTE, $1971^{1}$

${ }^{1}$ Rafael Conte na Apresentação do livro La literatura y el mal de Georges Bataille (2000, p. 8).

${ }^{2} \mathrm{~A}$ "feitiçaria, magia e bruxaria", até meados do século XX, encontram-se no Código Penal Brasileiro (Artigos 156, 157 e 158), que vigorou até a década de 1940 ; nele há prescrições com penalidades a estas condutas, caracterizando-as como fonte promotora de danos físicos, psíquicos e sociais. Salienta-se ainda que tais danos incluem não só a dimensão do ódio, mas também a dimensão da sedução. (Artigo 157, do Código Penal Brasileiro).

3 Instituto do Patrimônio Histórico e Artístico Nacional (originalmente designado como Serviço do Patrimônio Histórico e Artístico Nacional SPHAN).
O objetivo deste estudo é trazer à reflexão os contornos de uma investigação histórico-cultural, pontuando singularidades literárias expressas por dois poetas brasileiros acerca das representações do particular e do universal. $\mathrm{O}$ nosso ponto de partida dar-se-á a propósito do caso específico da patrimonialização da coleção-museu de magia negra em 1938. O pano de fundo da reflexão atinge o vasto campo do imaginário artístico do período modernista nas primeiras décadas do século $X X^{2}$.

Este trabalho seguirá a trilha já traçada por Antonio Candido na obra Literatura e Sociedade ([1965] 2000) na qual o autor se refere à "lei de evolução da vida espiritual brasileira". (p. 101) Nesse livro Candido sugere que a dialética do localismo e do cosmopolitismo regem essa evolução espiritual, no embate entre o nacionalismo literário e a imitação dos padrões europeus. Esse embate tanto se dá no plano dos "programas" quanto no plano "psicológico", concluindo que esse processo evolutivo em causa depende do "equilíbrio entre essas duas tendências". Em nossa pesquisa observamos a precisão dessas colocações no caso da comparação aqui sugerida.

A Coleção de Magia Negra, inscrita como primeiro patrimônio etnográfico brasileiro, consta da lista de tombamentos do IPHAN ${ }^{3}$ desde 1938. Descobrimos que Dante Milano foi o primeiro diretor do Museu da Polícia Civil, no qual repousa salvaguardada a referida coleção. $\mathrm{O}$ poeta carioca dirigiu a instituição por quase duas décadas. Esse dado biográfico revelou veredas interpretativas surpreendentes.

No livro Museu Mefistofélico (Corrêa, 2009) o foco original da pesquisa versava sobre a Coleção de Magia Negra. A obra e a vida do poeta ficaram em um plano subjacente no trabalho. Ao retomar a escavação arqueológica do processo de tombamento dessa Coleção, centramos o foco sobre as diferenças entre as posições de Mário de Andrade, como membro do Serviço do Patrimônio Nacional (SPHAN), e Dante Milano, como diretor do Museu da Polícia, em relação 
4 Museu da Polícia Civil do Rio de Janeiro hospeda até hoje a Coleção-Museu de Magia Negra, tombada pelo SPHAN em 1938. Dos anos de 1910 até os anos de 1930, ocorreram diversos processos e ações policiais contra terreiros de candomblé. E foi nesse Museu da Polícia, do Distrito Federal, que foram guardados vários objetos e peças classificadas como magia, feitiçaria e bruxaria. Tanto no Rio de Janeiro, como em Recife e em outras partes do país, na mesma época, ocorreram essas ações. Mário de Andrade chegou a recolher objetos e peças provenientes de Recife para sua Coleção particular, hoje preservada no Instituto de Estudos Brasileiros/USP. Como se sabe, até o ano de 1948 o Código Penal Brasileiro enquadrava o charlatanismo e a prática de magia como crime. à magia e seus derivados socioculturais classificados como patrimônio cultural. Esse movimento interpretativo pode contribuir para esclarecer obscuridades ainda presentes nessa história preservacionista singular.

Para compor um fio narrativo sublinhamos alguns aspectos sociais e culturais do processo de criação da ColeçãoMuseu de Magia Negra, do seu tombamento e da criação do Museu da Polícia Civil do antigo Distrito Federal do Rio de Janeiro ${ }^{4}$. A Coleção de Magia resulta de diligências policiais acionadas por processos de acusação e denúncias ocorridas nas primeiras décadas do século XX. Ressalta-se que esse período se caracteriza pelo predomínio hegemônico de concepções positivistas, sanitárias e higienizadoras. Nessa coleção museológica reuniram-se utensílios, objetos e peças apreendidos nas Delegacias do antigo Distrito Federal, de acordo com o Código Penal vigente até 1946. Cabia à Primeira Delegacia Auxiliar: "I - Processar a cartomancia, mistificações, magias, exercício ilegal da medicina e todos os crimes contra a Saúde Pública." O tombamento desse conjunto museológico heteróclito acompanha os processos que foram promovidos principalmente por Mário de Andrade no antigo SPHAN. Tais ações de salvaguarda desencadearam a preservação de diversos conjuntos de peças e objetos que hoje se encontram em diferentes instituições museológicas do país. Destacam-se as coleções do Museu do Estado de Pernambuco, Casa Câmara Cascudo em Natal/RN, Coleção Arthur Ramos em Fortaleza, Coleção Perseverança em Alagoas etc.

Neste texto nossa atenção se fixará no contexto mais específico do modernismo literário brasileiro, entendido como um movimento efervescente de ideias estéticas e políticas atingindo seu auge na década de 1930. Nosso intuito aqui é comparar as posições de Dante Milano e Mário de Andrade, em particular sobre as representações acerca do folclore, cultura popular e manifestações religiosas. Esse trabalho de comparação se fará à luz da teoria sugerida por Antonio Candido, apresentada logo no início desse texto. Para esse autor o "local" (ou o particular) constitui a "substância da expressão", enquanto o "geral" (ou universal) constitui a "forma da expressão"; no caso identificada com a "tradição europeia" (p. 101). É essa dialética do universal e do particular que veremos se processar na comparação entre os dois poetas estudados. 
5 Antonio Candido é
especialmente impor-
tante para esse estudo,
pois seguimos de perto
as posições de Mari-
za Peirano atestando
o pluralismo do autor
ao transitar de modo
fecundo entre a Socio-
logia, a Crítica Literária
e a Antropologia (PEIRANO, 1992).

6 Na correspondência de Mário de Andrade e Manuel Bandeira, encontram-se passagens em que se faz referência direta a Dante Milano: "Espírito singular, retraído e desconfiado" (escrito por Manuel Bandeira). Mário de Andrade chega a expressar a opinião de que Dante Milano era um "parasita de Jaime Ovalle". Esses comentários foram feitos nos anos de 1925 e 1926. (ANDRADE; BANDEIRA, 2000, p. 259).

7 No Rio de Janeiro, quem estava no Museu da Polícia, nessa ocasião, era Dante Milano. Existe um ofício de Rodrigo de Mello Franco de Andrade endereçado ao poeta solicitando o inventário das peças de "magia, feitiçaria e bruxaria" capturados pela polícia no início do século XX. Dante Milano respondeu ao ofício intitulando a coleção de "magia afro-brasileira".

8 É importante ressaltar neste contexto os elementos didáticos que aparecem do curso ministrado por Dina Lévi-Strauss, na jovem Sociedade de Etnografia e Folclore (SEF), fundada em 1934 ligada ao Departamento de Cultura do Município de São Paulo, dirigido por Mário de Andrade. Sobressai a ideia de uma Revista do Arquivo Municipal com a rubrica Arquivo Etnográfico, na qual haveria "uma seção destinada ao maior conhecimento do povo brasileiro" com "um formulário geral das pesquisas etnográficas a serem feitas no Brasil".
Nesse trabalho, vamos introduzir aspectos biográficos e literários, no exercício da comparação implementada ${ }^{5}$.

Como é sabido, após o afastamento de Mario de Andrade do Departamento de Cultura do Município de São Paulo (19357), o escritor paulista passou um breve período de sua vida morando no Rio de Janeiro; temporada designada de "exílio carioca" (1938-41). A sua chegada à capital federal coincide com o ano de inscrição da Coleção-Museu de Magia Negra no livro do Tombo do antigo SPHAN. E como se supõe, com toda certeza, Dante Milano - na época chefe de gabinete do Secretário de Segurança Pública e futuro diretor do Museu da Polícia - e Mário de Andrade travaram relações muito mais que esporádicas na vida boêmia da Lapa; em companhia de amigos e parceiros em comum. Na vasta correspondência epistolar do escritor paulista existem registros de impressões pessoais que tinha do poeta carioca ${ }^{6}$. Ressalta-se ainda o fato de o ofício que solicita o inventário da Coleção-Museu de Magia Negra ter sido recebido por Dante Milano; enquanto secretário do Gabinete de Segurança Pública do Distrito Federal ${ }^{7}$.

Portanto, é no encontro entre estes três vértices que compõem o triângulo dessas relações, de pessoas e de coisas, que nos situamos aqui, qual seja, entre Mário de Andrade, a Coleção de Magia Negra e Dante Milano. As particularidades e características dessas relações pessoais, objetivas e subjetivas, entre estes dois poetas e a Coleção em tela, constituem o objeto privilegiado desse estudo.

Cabe sublinhar logo de início que, diferentemente de Mário de Andrade, o poeta Dante Milano até hoje é uma personagem praticamente desconhecida do grande público. Destino totalmente diverso dos seus colegas modernistas, a grande maioria reconhecidos como artistas, intelectuais e acadêmicos ilustres ou célebres no espaço social literário brasileiro.

Como está apontado no texto, percebe-se com facilidade que Dante Milano destoa de modo particularmente especial dos confrades, não só no estilo de vida - avesso como foi à fama e à glória -, mas na forma como aderiu ao modernismo, e, principalmente, na sua concepção sobre a linguagem. De modo diferenciado dos outros tantos artistas da época, Dante Milano não toma a arte primitiva, a etnografia ou o folclore, como objeto de pesquisa para realização de sua poética ${ }^{8}$. Em nenhum momento de sua obra, encontramos o colorido dessas 
Como se sabe, no Boletim da SEF seguiu-se com as instruções folclóricas para pesquisa de campo preparadas por Dinah Dreyfus e Claude Lévi-Strauss.

9 Epígrafe do presente texto retirada da citação de Rafael Conte (BATAILLE, 2000, p. 8).

${ }_{10}$ Como aprofunda Antonio Candido: "Mário de Andrade, em Macunaíma (a obra central e mais característica do movimento), compendiou alegremente lendas de índios, ditados populares, obscenidades, esteriótipos desenvolvidos na sátira popular, atitudes em face do europeu, mostrando como a cada valor aceito na tradição acadêmica e oficial correspondia, na tradição popular, um valor recalcado que precisava adquirir estado de literatura" (MELLO ESOUZA, 2000, p. 110-1).

${ }^{11}$ Usamos o termo "modernista" para caracterizar um período da história literária brasileira. Pois veremos que Dante Milano não pode ser enquadrado nessa etiqueta quando analisamos sua obra literária. Milano já está pronto quando se inicia esse movimento artístico, e de modo algum se deixa influenciar pelos modismos que lhe são próprios. Entrevista de Dante Milano a Denira Rozário, em 1987: “Eu pessoalmente não queria ser poeta. Não me introduzi no meio abertamente. Porque eu não era modernista e não sou modernista. Mas como eu fazia parte de um movimento que ficou com esse nome, acho justo que me chamem de modernista porque eu pertenci a esse movimento" (NEVES, 1996, p. 97). cenas ganhar o relevo que conhecemos nas obras de Mário de Andrade. Como veremos aqui, os costumes, os traços cotidianos, as ruas, os homens e mulheres do dia-a-dia jamais se revelaram em Dante Milano com os destaques com que surgiram na obra do escritor paulista.

Desse modo, consideramos que ao contrário da visão de Mário de Andrade - assim como de Arthur Ramos e Gilberto Freyre, entre outros -, Dante Milano percebia "o mal e o bem (...) como dois elementos irreconciliáveis e perfeitamente inseparáveis da natureza humana"9, isto é, como expressões simbólicas do mundo que integra a superfície e o subterrâneo e que povoava sua imaginação poética, alimentada pelas leituras dos clássicos como Dante Alighieri e dos modernos como Charles Baudelaire e Arthur Rimbaud...

Mário de Andrade, e os outros autores citados, procuravam integrar a religiosidade popular e o folclore na cultura brasileira mestiça. Deve-se recordar, por exemplo, da descrição que há em Macunaíma, do terreiro da Tia Ciata, muito frequentado na antiga Praça Onze, no Centro do Rio de Janeiro. Obra em que se pode retirar os princípios de uma teoria étnica nacional ${ }^{10}$.

Considerando as particularidades dos grupos e indivíduos participantes desse drama social aqui enfocado, nos esforçamos no sentido de tentar compreender quais estruturas de sentido sustentavam as diferentes visões e concepções sobre significado cultural dos fenômenos sociais ligados à magia, o folclore e demais manifestações populares, e de que modo adquiriram valores diversificados, para os diferentes artistas e intelectuais referidos.

Percebemos então dois polos distintos de representação das manifestações mágico-religiosas, entre estes artistas e intelectuais "modernistas"11. De um lado tem-se a ideia de que essas manifestações seriam produto de 'mentes prélógicas', 'primitivas', 'analfabetas' que no processo avançado de educação e instrução seriam inexoravelmente abandonadas e esquecidas. De um modo geral essa concepção perpassa as obras de positivistas de Oliveira Vianna e de sanitaristas como Nina Rodrigues, Arthur Ramos, Ulisses Pernambucano etc.

Num misto de evolucionismo clássico, materialismo histórico marxiano e psicologismo freudiano, então em voga, intelectuais e artistas modernistas brasileiros, passaram a considerar essas manifestações como vestígios de um tempo 
12 Sobressai a trajetória de Arthur Ramos (19031949) que na sua luta contra o racismo conduziu trabalho pioneiro ao assumir o cargo de primeiro Diretor do Departamento de Ciências Sociais da UNESCO; tornando-se figura proeminente no processo de reconstrução do mundo do pós-guerra, defendendo a democracia. Acreditava que através da utilização dos recursos educacionais se pudesse superar a violência dos preconceitos raciais (Arquivo Arthur Ramos, 2004).

13 “Desde os últimos anos do império e desde a instauração do regime republicano, em 1889, as discussões sobre esse tema centravam-se na ideia de 'raça'. Ao longo da segunda e terceira décadas do século $\mathrm{XX}$, o problema veio a ser discutido, não mais em termos raciais, mas culturais, como uma busca da 'brasilidade', de uma 'essência', de uma 'alma', ou simplesmente 'identidade' da nação brasileira. Nos anos vinte e trinta, diferentes respostas foram apresentadas. Aqueles intelectuais identificados com o modernismo e associados ao regime político do Estado Novo concebiam a si mesmos como uma elite cultural e política cuja missão era 'modernizar' ou 'civilizar' o Brasil, elevando o país ao plano das nações europeias mais avançadas" (GONÇALVES, 1996, p. 41).

${ }_{14}$ Carta especialmente interessante, pois alinhava toda uma concepção articulada com Manuel Bandeira para o "programa" modernista: "O que nós todos queremos (o que pelo menos imagino que todos queiram) é obrigar este velho e imoralíssimo Brasil arcaico e que tenderiam a desaparecer no horizonte da evolução da civilização brasileira. Essa concepção sustentava o empreendimento de salvaguarda, registro e museografia desses acervos prestes a desaparecer devido ao incremento do processo acelerado de urbanização e industrialização do país.

No estudo mais específico das representações que o grupo modernista elaborou sobre o tema mais particular da magia, sobressai a figura intelectual de Arthur Ramos; fora do círculo literário ${ }^{12}$. Temos aqui um pensador que elaborou teses sobre as manifestações mágico-religiosas presentes na sociedade brasileira no mesmo patamar que Gilberto Freyre, operando transformações profundas no campo epistemológico das ciências sociais da época; no que tange especialmente aos estudos sobre raça, etnia e cultura. Veja-se, por exemplo, o que escreveu Arthur Ramos no livro O Negro Brasileiro, publicado em 1934, que sintetiza um pensamento modernista típico da primeira metade do século XX:

[...] para a obra da educação e da cultura, é preciso conhecer essas modalidades do pensamento 'primitivo', para corrigilo, elevando-o a etapas mais adiantadas, o que só será conseguido por uma revolução educacional que aja em profundidade, uma revolução 'vertical' e 'intersticial' que desça aos degraus remotos do inconsciente coletivo e solte as amarras pré-lógicas a que se acha acorrentado. (RAMOS, 2001, p. 32).

O problema nacional passa a não ser mais fundado na questão racial ou étnica, e sim na 'revolução educacional' necessária e inexorável. Lutando contra as teses racistas, esses escritores, artistas e intelectuais propunham uma ação civilizatória com base nas transformações subjetivas, sociais e culturais da existência coletiva ${ }^{13}$. Esse é um dos polos em que situamos a título de exposição didática o problema conceitual da pesquisa, qual seja, a dialética das representações sobre essas manifestações mágico-religiosas. Mário de Andrade se enquadra bem nessa posição com destaque, como se pode ver nessa citação de 1924, de uma carta ${ }^{14}$ a Carlos Drummond de Andrade, na qual define seu "programa", situando-se na dialética do "particular" e "universal": 
dos nossos dias a incorporar-se ao movimento universal das idéias. $\mathrm{Ou}$, como diz Manuel Bandeira, 'enquadrar, situar a vida nacional no ambiente universal, procurando o equilíbrio entre os dois elementos'" (ANDRADE, 1982, p. 14).

${ }_{15}$ Não deixa de ser irônico o fato de que, no "Obituário" de Dante Milano, publicado em 16 de abril de 1991, apareçam estampadas as contradições do uso da etiqueta "modernista": "UM POETA PÓSTUMO: último modernista deixa obra que vai ser conhecida agora. Desapareceu o último modernista. Mais conhecido e admirado do que lido, morreu ontem o poeta Dante Milano, aos 91 anos. Apesar de ter feito parte da $\mathrm{Se}$ mana de 22, ao lado do grande amigo Manuel Bandeira, Oswald de Andrade e Mário de Andrade, Villa-Lobos, Portinari, Di Cavalcanti e tantos outros, que não se cansaram de elogiar sua obra e seu talento, ele não gostava de ser rotulado de modernista e dizia, inclusive, ter horror à palavra moderno: - Como eu não queria ser poeta, não me introduzi no movimento abertamente, só por intermédio de Manuel Bandeira. Porque eu não era modernista, não sou modernista...".

16 Entrevista concedida para o vídeo Tudoé Exílio de André Andrias.
Nós só seremos civilizados em relação às civilizações o dia em que criarmos o ideal, a orientação brasileira. Então passaremos do mimetismo pra fase da criação. e então seremos universais, porque nacionais. $(1982$, p. 16)

No outro polo encontramos o pensamento de Dante Milano. Todos os dados recolhidos na investigação que realizamos e publicamos no ensaio Museu Mefistofélico (CORRÊA, 2009) indicam que Dante Milano possuía uma ideia ou representação muito distinta daquela apresentada mais acima. Como escreveu Sérgio Buarque de Holanda, em Dante Milano testemunhamos uma obra poética na qual a "poesia tem uma realidade independente da matéria que serviu para sua criação, é por assim dizer exterior a essa matéria, participando muito mais do espírito de seu criador" (Holanda, 1978, p. 122-3).

Nesse momento introduzimos diversos depoimentos em que Dante Milano se situa distante das posições e concepções de Mário de Andrade sobre diversos temas relacionados ao movimento modernista, à brasilidade, ao português falado no país, às manifestações culturais populares, aos demais parceiros e companheiros etc. Nesses trechos destacados de depoimentos e entrevistas, compreendemos bem a distinção entre os dois poetas.

Em entrevista a Denira Rozário em 1987, Dante Milano (DM) afirma categoricamente sua aversão à ideia de algo como 'brasileirismo':

DM - Para mim não existe brasileirismo em arte nenhuma. Não há pintura brasileira, poesia brasileira. Poesia ou é poesia ou não é poesia. Eu não me considero um poeta brasileiro. Me considero um poeta, em qualquer língua. E se vou à imprensa de língua portuguesa, sou um poeta português (Neves, 1996, p. 115).

No que tange ao movimento modernista ${ }^{15}$ propriamente dito, em entrevista a Ivan Junqueira no mesmo ano ${ }^{16}$, esclarece:

Ivan Junqueira (IJ) - [...] seu comprometimento com o modernismo, o seu, o do Bandeira, nãoéum comprometimento ortodoxo. O modernismo, a Semana de Arte Moderna de 22, é uma coisa muito paulista, não é?

Dante Milano (DM) - Inteiramente paulista. 
17 Sobre as particularidades do movimento no Rio de Janeiro: Essa gente do Rio... no qual a autora afirma: "Por tudo que viemos sugerindo [...], talvez seja possível encaminhar a ideia de que o Rio de Janeiro foi mais moderno que modernista, sem deixar, contudo, de abrigar debates e toda uma diversificada produção artística que alterou e revigorou sua própria tradição intelectual." (GOMES, 1993, p. 75).

${ }_{18}$ Entrevista realizada em Petrópolis, dia 27 de setembro de 2009.

19 Dante Milano no poema "Vozes Abafadas" escreveu: "A dor dos homens não se pode exprimir em nenhuma língua" (2004, p. 57); coerente enfim ao verso que conclui o poema "Princípio da Noite": "Tudo é exílio" (2004, p. 46).

${ }^{20}$ Sobre esse aspecto Antonio Candido escreveu: "A referida dialética [do local e cosmopolita] e, portanto, grande parte da nossa dinâmica espiritual, se nutre deste dilaceramento, que observamos desde Gregório de Matos no século XVII, ou Claudio Manuel da Costa no século XVIII, até o sociologicamente expressivo grito imperioso de brancura em mim de Mário de Andrade - que exprime, sob a forma de um desabafo individual, uma ânsia coletiva de afirmar componentes europeus da nossa formação" (MELLO E SOUZA, 2000, p. 102).
IJ - Como é que vocês foram mobilizados? Porque eu sei que o movimento no Rio não teve a mesma repercussão que em São Paulo ${ }^{17}$.

DM - O que aconteceu foi o seguinte: o Mário de Andrade veio ao Rio de Janeiro e ligou-se ao Manuel Bandeira. O Manuel ficou como sede do movimento modernista no Rio. Houve desde o início uma luta interna lá em São Paulo, entre Mário de Andrade e Oswald de Andrade, porque ambos queriam ser os chefes. Mas o Mário era muito mais trabalhador, muito mais ativo e dominou a situação, ficando chefe desse movimento modernista. Porque no Rio outro movimento modernista, do Graça Aranha, que foi escandalosissimo, ao menos para nós. Quando Graça Aranha abandonou a Academia Brasileira de Letras com um discurso-bomba, em 23... 24, por aí. O movimento modernista do Graça Aranha, que foi anterior do de São Paulo, ninguém fala mais. Na época foi muito mais importante porque tinha poetas como Ronald Carvalho, Guilherme Almeida, que depois foi viver em São Paulo, tinham um modernismo não abrasileirado. (Grifo nosso)

Sobre o mesmo tema o escritor Fernando $\mathrm{Py}^{18}$ situa Dante Milano na cena poética brasileira:

\begin{abstract}
AFC - Qual o lugar de Dante Milano na História da Poesia brasileira?

FP - Ele fica como um dos bons representantes do século XX. Agora, ele será sempre, me parece, enquadrado dentro da sua geração, a geração modernista. Por que ele é moderno, não será moderno no sentido de Mário de Andrade, mas é moderno no sentido de evolução e de propor certas soluções de ritmo, no verso, e de vocabulário; um vocabulário mais extenso, a maneira de tratar a ideação, a sintaxe. Então, isso representou um lado moderno nele. Então, ele é moderno mesmo não tendo estreado junto com os modernos.
\end{abstract}

Ao ser indagado sobre as possibilidades de uma "língua brasileira"19, ideia defendida por Mário de Andrade, Dante Milano não deixa dúvidas sobre sua discordância quando responde a Ivan Junqueira:

IJ - Não havia aqui no Rio, uma preocupação de reinventar uma língua, não é?

DM - Não, reinventar a língua foi só o Mário. Os outros não. Para Mário era uma questão racial. Ele era de origem africana ${ }^{20}$. Mas no Manuel Bandeira você encontra isso rarissimamente. 
IJ - Você não encontra em mais ninguém. Há uma tentativa em São Paulo da parte do Mário com Macunaíma., depois da parte do Cassiano Ricardo com Martim-Cererê e do Monteiro Lobato que, aliás foi ante-modernista, com Jeca Tatu. [...] Nessa época esse movimento tinha [...] os olhos voltados para a brasilidade. Até que ponto isso atingiu você, ou chegou a modificar essa visão com relação ao fenômeno poético?

DM - Não, não modificou. Somente influenciou um pouco. Porque naquela época, eu escrevia sobre carnaval, em prosa e verso. O quê um carioca poderia fazer para ser brasileiro? Se preocupar com as manifestações brasileiras. [...] O Mário de Andrade era um talento poético muito grande, mas a criação de uma linguagem brasileira eu acho um erro. [...] Na realidade o que eles ("modernistas") queriam era o verso livre (Neves, 1996, p. 123-4).

Fernando Py confirma a posição de Dante Milano em relação a possibilidade de uma "língua brasileira", numa entrevista que realizamos em 2009:

AFC - D.M. não compartilhava da ideia nacionalista de Mário de Andrade em querer criar um língua 'brasileira'?

FP - Exatamente, ele não gostava. Ele não era dessa vertente. O Drummond ele gostava... O Drummond também era muito parecido com Mário de Andrade, mas só que deixou uma obra poética muitíssimo superior. A grandeza de Mário de Andrade não está na poesia, está no ensaio, no folclore, na música, nos estudos sobre música; ele era muito mais... Tudo isso está no Macunaíma (1928). Quer dizer, então, a poesia dele tem momentos, momentos excelentes, como o principal que é a Meditação do Tietê (1945), o grande poema dele; no final do Poesias Completas (1955). Agora, ele teve a vantagem, ou a ideia, ou a circunstância principal, de abrir o caminho para, definitivamente, ser a poesia, enfim, totalmente livre dos ranços parnasianos, inaugurada com Paulicéia Desvairada (1922). Aí, sim, mas é um momento, depois ele ficou mais ou menos naquilo, sem criar nada demais, por isso que ele é um poeta menor.

${ }^{21}$ Mefistófeles: "O espírito que nega tudo" (BERMAN, 1986, p.83)

Temos um perfil de Dante Milano traçado com mais nitidez. Formado na literatura clássica que vem desde Horácio, Virgílio, Dante Alighieri, Leopardi, depois os modernos Charles Baudelaire, Arthur Rimbaud e Stéphane Mallarmé, entre outros, o poeta elabora uma visão 'mefistofélica' ${ }^{21}$, expressando de forma contundente, nos seus textos poéticos e literários - como nas entrevistas concedidas em vida -, suas 
${ }^{22}$ Ainda sobre o modernismo, em entrevista de Dante Milano a Denira Rozário: “Não havia nada de tão importante no movimento modernista como depois se propalou. Era uma influência, que eu já na época achava péssima, de Marinetti. Marinetti era um péssimo poeta. Entretanto a vantagem do movimento foi que acabou com o academicismo que dominava o Brasil, o Rio de Janeiro inteiro. Então, por esse motivo que eu aderi a ele" (NEVES, 1996, p. 97).

${ }^{23}$ Poder-se-ía ficar tentado a perguntar ainda, afinal Dante Milano acreditava em fantasma? Veja-se o que disse sobre o acidente que o imobilizou por longo tempo e que o impossibilitou de realizar as tão amadas caminhadas pela praia do Leme, no Rio de Janeiro: "Desde que eu morava no Leme, eu ia todo dia no Caminho dos Pescadores. Daquela pedra você vê um mundo do ponto de vista do oceano. É um assombro. Quando eu ia subindo pela última vez a escada que levava ao caminho, na hora de subir o degrau eu senti fraqueza na perna, ai eu voltei e pus a outra pra ver se eu subia. Então senti uma coisa verdadeiramente estranha; um empurrão, como se fosse um fantasma que me tivesse empurrado, e caí" (NEVES, 1996, p. 104). divergências em relação à obra de Mário de Andrade e ao movimento modernista.

Sua obra literária e poética reflete uma particularidade significativa, com relação a essa temática, o que deve ter guiado o seu trabalhado como diretor do Museu da Polícia Civil, lugar onde se encontra até hoje a Coleção-Museu de Magia Negra. Seu comportamento singular, sempre marcado por distinções deliberadas, avesso a associações simples com o modernismo em voga, espelham esta marcante diferenciação de traços e ideologia ${ }^{22}$. Essa constatação pode ser sedimentada no registro de uma resposta a uma pergunta direta na mesma entrevista concedida a Denira Rozário (DR), em 1987, em que Dante Milano (DM) explicita seu pensamento sobre a existência do bem e do mal:

DR: - Então Milano, fale dessa sua fascinação pelo macabro e pelas trevas e ao mesmo tempo dessa sua obsessão pela luz.

DM: - Isso eu aprendi com a natureza. Quando vejo uma tempestade, quando eu vejo um furacão, eu vejo um mundo diferente. Eu sinto perfeitamente quando vejo a luz, que ela vem da treva. O sol nasce da noite. Primeiro é a noite, depois vem o sol. Quer dizer, há uma grande ligação entra a luz e as trevas. Inseparável. Uma depende da outra. Desde criança eu sei. Quando havia tempestade eu ficava olhando o céu. Aquela modificação acima do meu entendimento. Hoje eu estou completamente certo que se não existisse uma a outra não existiria (Neves, 1996, p. 102) ${ }^{23}$.

Destarte, fica delineada a discrepância das posições distintas que os dois artistas tinham sobre as mesmas manifestações: de um lado uma visão mais de folclorista, que prevê um trabalho de preservação patrimonial, de bens culturais que vão inexoravelmente desaparecer em função da evolução social e educacional da civilização brasileira; revelando uma espécie de nostalgia pela perda do passado mágico e encantado. Quando se lê o livro Macunaíma (1928) percebe-se que se trata de uma narrativa impregnada de feitiços e magias, ditados, chistes e sátiras populares, assim como lendas e mitos indígenas e africanos, entre outras tantas "componentes recalcadas da nacionalidade", segundo Antonio Candido (2000, p. 111). Nessa direção, podemos destacar especialmente o capítulo VII intitulado Macumba, em que se narra a visita do herói ao terreiro de Tia Ciata no Rio de 
${ }^{24}$ No seu intrigante artigo, traduzido para o francês como Digressions surl'Étranger, de 1908, G. Simmel, escreveu: "O estrangeiro instala-se na comunidade, mas fica à margem. Não apreende seus mecanismos íntimos e permanece de certo modo exterior ao grupo social, o que lhe confere, involuntariamente, uma maior objetividade, 'que não implica o distanciamento ou o desinteresse, mas resulta antes da combinação específica da proximidade e da distância, da atenção e da indiferença'" (apud COULON, 1995, p. 56).

${ }^{25}$ Mariza Peirano recupera a tese de Marcel Mauss sobre a magia, quando aponta para o fato de Antonio Candido ter seguido essa lição ao comparar "a poesia, a música, os ditos populares, em diferentes sociedades" (1992, p. 45).

${ }^{26}$ Alusão ao título do livro da antropóloga Ivonne Maggie, Medo do feitiço (1992).
Janeiro. É o momento e que a personagem principal do enredo busca através de Exu fazer sofrer o gigante Piaimã comedor de gente, Venceslau Pietro Pietra, que ainda estava de posse da pedra verde muiraquitã.

Já no outro polo, a posição de Dante Milano - mas não de um 'grupo', e sim de um indivíduo, artista isolado e marginal ${ }^{24}$ ao modernismo consagrado, avesso à fama e à glória, como ele mesmo se definia - um artista propriamente moderno, na acepção da palavra, para além dos encantamentos místicos ou religiosos. Em suma, considerando que "só há magia quando esta é reconhecida socialmente"25 (Peirano, 1992, p. 44), Dante Milano foi um poeta brasileiro que não tinha "medo de feitiço"26, habitando a fronteira, o limiar, a margem de uma estrutura de sentido dominante e hegemônica.

Mas, em meio a toda essa movimentação da pesquisa, sobressai uma indagação: o que fazia um poeta como Dante Milano na direção do Museu da Polícia Civil? Em entrevista concedida a Denira Rozário, na presença de Ivan Junqueira, em 1987, ele afirma categoricamente que esse assunto era 'confessional'. A natureza 'confessional', mais subjetiva, das estruturas de sentido, que sustentaram os atos e as representações do agente humano em questão, não foram expressas de modo direto, como nos outros temas abordados por ele. Então, como ultrapassar essa panóplia, esse oculto sob o véu do silêncio?

Mesmo na pesquisa mais próxima e minuciosa de seus arquivos particulares, dos depoimentos das pessoas ainda vivas que conviveram com o poeta e na sua obra poética e literária, pouco podemos acessar sobre suas ações na direção do órgão. Sabemos apenas, através de sua esposa Alda Milano, que ele foi o organizador do museu na ocasião de sua fundação: num trabalho que sentiu prazer em fazer. E nada mais nos é oferecido como testemunho de seu tempo museológico.

Na entrevista com Ivan Junqueira obtivemos o seguinte depoimento: 
Pública, a Polícia, a Museologia... Numa entrevista que ele oferece à Denira Rosário...

IJ - Fui eu que a apresentei a Dante Milano...

AFC - Nessa entrevista, o poeta afirma que esse assunto era 'confessional'. Eu lhe pergunto, não seria antes 'confidencial'?

IJ - Confessional; confidencial, não. Porque o D.M. tinha uma inclinação pessoal muito grande pelos aspectos sinistros da vida. Coisa lá do temperamento dele. E a sensação que eu tenho é que ele se deu muito bem nesse Museu da Polícia. Cuidando daquelas monstruosidades... ${ }^{27}$. (Grifo nosso)

Ao insistirmos com Ivan Junqueira sobre o período em que Dante Milano dirigiu o Museu da Polícia, registramos o seguinte:

AFC - A natureza da atração do poeta pelo sinistro, tão enfatizada pelos críticos e analistas de sua poética; sua simpatia por Augusto dos Anjos, Baudelaire... seu fascínio pelo macabro e pelas trevas (que nos lembra Edgar Poe) - sua obsessão pela luz... Tudo isso expresso num vasto vocabulário, em vasto léxico e ricos adjetivos... Tudo isso não caberia bem no cenário do Museu da Polícia, dirigido por ele, no qual contém coleções muito semelhantes ao que é referido na sua obra? O Sr. conhece o Museu?

IJ - Caberia, sim. Mas não conheço o Museu... Esse Museu ainda existe?

AFC - Sim, existe. O prédio e a coleção museológica são tombados pelo patrimônio cultural estadual e tem uma coleção de magia que é tombada pelo IPHAN, desde 1938... [...] Uma coisa que a gente não pode responder, só o Dante poderia responder, é o seguinte: esse fascínio pelo macabro, que realmente existe na poesia dele, veio antes ou depois da experiência dele como diretor do Museu da Polícia; ninguém pode responder a isso. Quem é que vai responder a isso?

Ao direcionarmos a entrevista para as possibilidades de relação entre a poética de Dante Milano e o acervo museológico da magia negra, Ivan Junqueira arrisca algumas considerações:

${ }^{27}$ Entrevista com Ivan Junqueira na Academia Brasileira de Letras, Rio de Janeiro, no dia 02 de setembro de 2009.
AFC - Não teria essa coleção uma relação mais profunda com o imaginário do mal e do diabólico, na arte de D.M. e na arte moderna brasileira? Não só essa coleção, mas toda uma museologia construída a partir dessas peças e objetos?

IJ - Pode ter, pode ter. Mas sobre isso a gente nunca conversou. Quando eu conheci o Dante, em 1979, a experiência que ele 
teve no Museu da Polícia, já estava muito distante. Eram décadas e décadas, todas de esquecimento. Mas ele gostava muito de dizer que dirigiu o Museu da Polícia. Uma coisa que lhe deu enorme prazer, estar ali a frente desse Museu da Polícia.

AFC - Mas, o Sr. diria que ele sentiu 'prazer' em ter dirigido e vivido aqueles anos no Museu?

IJ - Era a função que ele desempenhava, ele gostava da função... meio estranha para um poeta. Mas se você for ler os trinta e três cantos do Inferno, aquilo ali é um outro museu... Aquilo ali é uma coisa patológica...

Dante Milano, como tradutor e estudioso das obras de Dante Alighieri e Charles Baudelaire, apresenta uma singularidade marcante na base de sua estruturação literária e poética. Ao escavarmos mais profundamente as camadas de sentido que estruturaram as imagens dialéticas sobre a magia em nossa sociedade, no início do século $X X$, e no começo do movimento modernista brasileiro, encontramos um poeta que brilha com sua própria luz.

Ao dirigir o Museu da Polícia por mais de vinte anos Dante Milano firmou sobre as coleções museológicas ali presentes - formadas por conjuntos heteróclitos de objetos apreendidos e por materiais didáticos para as aulas da Academia de Polícia: armas, uniformes, cenas de crimes, história da polícia, jogos de azar, charlatanismo etc., e a Coleção-Museu de Magia Negra - um olhar que não podia ser enquadrado de modo reducionista. No museu se encontravam diversos discursos imbricados; como descrevemos no texto de Museu Mefistofélico (2009). Todavia, é possível admitir que como poeta e com a formação clássica que tinha em literatura, Dante Milano concebia todo aquele acervo como a expressão do lado obscuro e sinistro da vida. Como escreveu Ivan Junqueira, Dante Milano era um poeta metafísico, perscrutando estruturas perenes do espírito humano:

IJ - Na verdade, eu acho que o amor pelo macabro, o amor pelo lado sinistro das coisas, vem do Dante Alighieri. Quem ler o Inferno do Dante Alighieri, verá que está cheio disso. E ele era um leitor quase cotidiano da Comédia. Eu tenho quase certeza que esse lado macabro do Dante Milano se desenvolveu à sombra da leitura da Divina Comédia . (Entrevista ao autor). 
De certa forma, nesse ponto nos aproximamos das reflexões de Georges Bataille $(1949,1989)$ nas quais o autor pretendeu desvendar a significação da "parte maldita" da existência humana. Na coleção de autores investigados por Bataille, certamente Dante Milano figuraria como exemplar. Os dois compreenderam que:

A humanidade persegue dois fins, de que um, negativo, $e ́$ conservar a vida (de evitar a morte), o outro, positivo, de lhe aumentar a intensidade. Estes dois fins não são contraditórios. Mas a intensidade jamais aumentou sem perigo; a intensidade desejada pela maioria (ou o corpo social) está subordinada à preocupação de manter a vida e suas obras, que possui um primado indiscutido. Mas, quando ela é buscada pelas minorias, ou pelos indivíduos, ela pode sê-lo sem esperança, além do desejo de durar. A intensidade varia conforme a liberdade maior ou menor. Esta oposição da intensidade à duração vale no conjunto, e reserva muitos acordos (o ascetismo religioso; do lado da magia, a busca dos fins individuais $\left.{ }^{28}\right)$. A consideração do Bem e do Mal deve ser revista a partir desses dados (BATAILLE, 1989, p. 64).

No ano que marca os 70 anos da morte de Mário de Andrade - em que há a retomada das "[...] questões ligadas à filosofia, às artes do fazer e às práticas de resistência das religiões afro, [tecendo-se] o elogio das diferenças étnicoraciais, culturais e religiosas que, afinal, compõem o Brasil imaginado por Mario de Andrade e seus seguidores no Departamento de Cultura [... $]^{1129}$ - também parece justo fazer a devida apreensão da heterogeneidade que marcou o movimento dito modernista no Brasil. Convém superar de vez a ideia de qualquer homogeneidade ou ortodoxia de escola.

28 Bataille acrescenta ainda: "Estes fins, é verdade, visam costumeiramente o excesso, não o Bem puro e simples, a conservação. Eles permanecem, por isso, favoráveis à intensidade." (1989, p. 64)

29 Trecho do texto enviado como carta convite para o evento $A$ MISSÃO DE PESQUISAS FOLCLORICAS 1938-2015, promovido pelo Centro Cultural São Paulo em outubro de 2015; no qual apresentamos versão original desse estudo. Percebemos a importância em compreender as distinções de um Oswald de Andrade, de um Graça Aranha, entre outros tantos, e agora também de um Dante Milano, especialmente na movimentação da dialética do particular e do universal. Essa herança fica como justo legado, ao fazermos os ajustes necessários, transmitido para as futuras gerações num desenho mais fidedigno do processo modernista.

Considerando as múltiplas faces de um drama tecido com vários fios narrativos, toma-se a liberdade de recuperar com ironia, para o desfecho desse texto, uma passagem do Macunaíma quando este solicita a intervenção de Exu para fazer sofrer o gigante Piaimã comedor de gente, Venceslau 
Pietro Pietra, que lhe diz: "- ... nome principiado por Ma tem má-sina..." ${ }^{\prime 30}$. Má-sina que Carlos Drummond de Andrade, no livro A rosa do povo de 1945, vai despetalar no poema “Mário de Andrade desce aos infernos":

... e uma rosa se abre, um segredo comunica-se, o poeta anunciou,

o poeta, nas trevas, anunciou.

[...]

os primitivos, os cantadores, a gente de pé-no-chão,

a voz que vem do Nordeste, os fetiches, as religiões,

os bichos... Aqui tudo se acumulou,

[...]. (ANDRADE, 2005, p. 187)

No Museu de Tudo ${ }^{31} \ldots$

${ }^{30}$ Má-sina que também é descrita no livro Mário de Andrade: a morte do poeta, de Eduardo Jardim (2005).

31 João Cabral de Melo Neto, Museu de Tudo (1976).

\section{REFERÊNCIAS}

ANDRADE, Carlos Drummond de. A rosa do povo. Rio de Janeiro: Record. 2005.

ANDRADE, Mário de. Poesias completas. São Paulo: Duas Cidades, 1950. . Macunaíma. São Paulo: Círculo do Livro, S/D. - A lição do amigo: cartas de Mário de Andrade a Carlos Drummond de Andrade. Rio de Janeiro: J. Olympio, 1982. ; BANDEIRA, Manuel. Correspondência. Org. Marcos Antonio de Moraes. São Paulo: Edusp/IEB, 2000, p.680. BATAILLE, Georges. La part maudite. Paris: Minuit, 1949. . A literatura e o mal. Porto Alegre: L\&PM, 1989. La literatura y el mal. Toronto: Ediciones Elaleph, 2000. BAUDELAIRE, Charles. As flores do mal. São Paulo: Max Limonad, 1981. 1981. . Meu coração desnudado. Rio de Janeiro: Nova Fronteira.

BERMAN, Marshall. Tudo que é sólido desmancha no ar: a aventura da modernidade. São Paulo: Companhia das Letras, 1986. 
CANDIDO, Antonio. Literatura e Sociedade: estudos de teoria e história literária. São Paulo: T. A. Queiroz/Publifolha, 2000. COLEÇÃO MÁRIO DE ANDRADE: Religião e Magia, Música e Dança, Cotidiano / Organizadora Maria Rossetti Batista. São Paulo: USP, 2004.

CORREAA, Alexandre F. Museu mefistofélico: análise do tombamento do primeiro patrimônio etnográfico do Brasil. São Luís: EDUFMA/ PGCult, 2009.

COULON, Alain. A escola de Chicago. Campinas, SP: Papirus, 1995.

GOMES, Ângela de Castro. Essa gente do Rio...: os intelectuais cariocas e o modernismo. Estudos Históricos, Rio de Janeiro. vol. 6, n. 11, 1993, p. 62-77.

GONÇALVES, José Reginaldo Santos. A retórica da perda. Rio de Janeiro: UFRJ/IPHAN. 1996.

HOLANDA, Sérgio Buarque de. Cobra de vidro. São Paulo: Perspectiva, 1978.

JARDIM, Eduardo. Mário de Andrade: a morte do poeta. Rio de Janeiro: Civilização Brasileira, 2005.

JUNQUEIRA, Ivan. O fio de Dédalo. Rio de Janeiro: Record, 1998.

MAGGIE, Yvonne. Medo do feitiço: relações entre magia e poder no Brasil. Rio de Janeiro: Arquivo Nacional, 1992.

MELO NETO, João Cabral de. Museu de tudo. Rio de Janeiro: José Oympio. 1976.

MILANO, Dante. Poesia e prosa. Org. e apres. Virgílio Costa. Rio de Janeiro: Civilização Brasileira: UERJ, 1979. . Dante Milano: obra reunida. Rio de Janeiro: ABL, 2004.

NEVES, Thomaz Guilherme Albornoz. Um certo Dante. Dissertação (Mestrado em Letras) - Pontifícia Universidade Católica do Rio de Janeiro, 1996.

PEIRANO, Mariza G. S. Uma antropologia no plural: três experiências contemporâneas. Brasília, DF : Editora Universidade de Brasília, 1992.

RAMOS, Arthur. O negro brasileiro. Rio de Janeiro: Graphia, 2001. . A mestiçagem no Brasil. Maceió: EDUFAL, 2004.

- Arquivo Arthur Ramos. Rio de Janeiro: Fundação

Biblioteca Nacional, 2004. 
RIO, João do. As religiões do Rio. Rio de Janeiro: Garnier, 1906. As religiões do Rio. Rio de Janeiro: Simões, 1951.

\begin{abstract}
Magic, poetry and spell: Between Mario de Andrade and Dante Milano

Cultural-historical study of literary singularities expressed by two Brazilian poets on the subject of cultural preservation of black magic collection in 1938. A reflection on the artistic imagination of the modernist period in the early decades of the twentieth century.
\end{abstract}

Keywords: poetry, Modernism, magic, literature. 